\title{
Forecasting bankruptcy in the wood industry
}

\author{
Tomasz Noga ${ }^{1} \cdot$ Krzysztof Adamowicz $^{1}$
}

Received: 8 August 2019 / Accepted: 23 October 2020 / Published online: 26 November 2020

(c) The Author(s) 2020

\begin{abstract}
The assessment of a company's financial condition is an effective tool, which supports the management system. Nowadays a number of models are available, most often multi-branch ones, which are able to predict the financial situation of an enterprise. Models solely intended for just one line of business are a rarity. As far as the wood sector is concerned, no homogenous model suited to the sector has been created. The article aims to present the final stage of research dealing with predicting bankruptcy in the wood sector. The bankruptcy prediction model presented in this paper, called the model for forecasting bankruptcy of wood enterprises (FMWE), has been developed specifically for the wood sector. The process of model construction was presented and the correctness of forecasts built with the use of FMWE was verified. The predictions were based on 1-, 2- or 3-year periods. Furthermore, the effectiveness of the FMWE projections was compared to the 10 most popular bankruptcy prediction models used in Poland. It was observed that in comparison with other prediction models, FMWE predictions for this particular industry indicate greater credibility, up to $90 \%$, for 1-year and 2-year predictions.
\end{abstract}

\section{Introduction}

The first theoretical aspects which focused on predictions concerning bankruptcies have at least a 50 -year long history (Altman 1968; Beaver 1966). The lender has to assess the risk involved in extending credit to a specific borrower including the ability and willingness to fulfill debt obligations. All the issues crucial to modelling borrowers' and lenders' behavior in an asymmetric information context are also relevant in designing the network of credit relationships (Gatti et al. 2009). The literature on this subject is constantly growing and developing; among other reasons, this is due to the fact that predictions which focus on dangers and hazards are used in numerous contexts dealing with business management (Jones 2017). Altman (2018) conducted a 50-year long retrospective assessment of credit risk models based on the multidimensional discriminant analysis and its applicability both to financial markets and managerial strategies. He concluded that despite its 'old age', the discriminant analysis may still be treated as a standardized analytical tool. Moreover, in his research, he drew special attention to

Krzysztof Adamowicz

adamowic@up.poznan.pl

1 Faculty of Forestry and Wood Technology, Poznan University of Life Sciences, Wojska Polskiego 28, 60-637 Poznań, Poland the position of the Altman Z-score formula in bankruptcy prediction studies, based on which most models for bankruptcy or insolvency are gauged; this formula is also often used by those working in the financial markets as well as researchers. In his article, Altman (2018) shared his thoughts on the evolution of Altman's bankruptcy prediction models together with their extensions and potential applications to financial markets and their role in the decision making process. Ribeiro et al. (2012) also noticed that especially in the last 30 years bankruptcy prediction has become a significant and difficult task and worked as an impulse for a number of studies, analyses and articles. Many scholars support this opinion (e.g. Adamowicz 2010; Abellán and Mantas 2014; Adamowicz and Noga 2014; Afik et al. 2016; Brezigar-Masten and Masten 2012; Chen et al. 2013; Delen et al. 2013; Ribeiro et al. 2012 and many others).

A critical overview of the subject literature and contemporary theoretical approaches connected with credit risk and bankruptcy was presented by Misankova (2016). The main aim of her research was to compare bankruptcy prediction methods published after 1963 in academic journals indexed in the Web of Science Core Collection and Scopus databases. On the basis of the literature on this subject, it is possible to determine key methodological problems connected with predicting bankruptcy. The lack of analyses and research focused on predicting financial hazard by means of homogenous (single-branch) predicting models can be 
viewed as one of the most important hindrances. Moreover, the need to construct such a model based on the specificities of both the domestic industry and a particular branch of industry has been noticed. This view has gained support from Antonowicz (2007), who indicated the necessity to construct an estimation model based on similar homogenous populations, which as a consequence may potentially increase the reliability of both the discriminant functions and the resulting predictions. The hypothesis has been supported by Prusak (2011) and Tymoszuk (2013), who emphasized the significance of constructing business models. Furthermore, Dąbrowska (2008) expressed the need to create a model intended for a narrow group of entrepreneurs so that it is not used indiscriminately for any other type of production.

It is worth noticing that currently attempts are made to create a methodological basis for predicting industrial changes as far as a single branch of industry is concerned. For example, Platt and Platt (2002) conducted research for the US car industry and indicated the need to construct and verify the forecasts based on the models focused on a single research sample. Furthermore, Wardzińska (2012) conducted a study on a homogenous research sample concentrating on Polish car companies and, on that basis, she designed prediction models. In turn, Nguyen et al. (2016) showed a bankruptcy prediction model for Vietnamese construction companies. Busu (2015) modified Altman's Z-Score calculations to fit the mobile telecommunication sector in Romania. Singh and Mishra (2016) presented a model for the retail industry sector in India. Moreover, in his study, Wędzki (2005) concluded that a model estimated based on a domestic, single-branch sample provides predictions by several percentage points more accurate than the standardized multi-branch one. His research supports not only the concept to create single-branch industry models, but also reveals its efficiency. It also is vital to notice that until now there has been no single homogenous model intended for the wood industry.

In Poland, problems connected with predicting the financial situation of wood industry enterprises have been investigated, for example by Adamowicz and Noga. Their studies allowed to assess and compare Altman's and Mączyńska's models in terms of their usefulness to predict bankruptcy of enterprises in the wood industry. The choice of these particular models was dictated by their high efficiency while assessing bankruptcy prognosis in other industry branches in Poland (Wędzki 2005). However, Adamowicz and Noga (2014) came to the conclusion that bankruptcy predictions for wood industry enterprises were made based on the models which were never very reliable for this particular industry. Together with Mączyńska's model, the efficiency of predicting bankruptcy for wood industry enterprises amounted to $84 \%$ in the case of 1 -year forecasts, $63 \%$ for 2 -year forecasts and $59 \%$ for 3 -year ones. The predictions constructed following Altman's model showed lower efficiency of 78\% for 1 -year, $60 \%$ for 2 -year and $57 \%$ for 3-year forecasts, respectively (Adamowicz and Noga 2014). Moreover, Noga et al. (2014) also conducted an efficiency assessment of bankruptcy predictions for wood industry enterprises, in which three other early warning models, very popular among Polish entrepreneurs, were adopted. These included: (i) Hołda's; (ii) Gajdka and Stos's; and (iii) Prusak's models.

In the context of the discussed topic, this work, which reviewed the efficiency of 10 bankruptcy prediction models in wood industry in Poland is of particular importance. Adamowicz and Noga (2017) compared: (i) Altman's, (ii) Gajdka and Stos's, (iii) Hadasik's, (iv) Hołda's, (v) Jagiełło's, (vi) Mączyńska's, (vii) Poznański's, (viii) Prusak's (1), (ix) Prusak's (2) and (x) Wierzba's models. These prediction models were subjected to the efficiency assessment test, i.e. the Enterprise Classification Matrix (ECM). The efficiency analysis, which focused on classifying wood sector enterprises based on whether they were or were not threatened with bankruptcy, indicated that the average verifiability of these predictions for the methods was $74 \%$. One of the elements influencing the efficiency of these predictions was the data collection period considered in order to create the forecast. In the case of predictions based on a 1-year period prior to the forecast, the efficiency was $77 \%$, for the 2 -year ones $70 \%$, while for the 3 -year ones it was $75 \%$. It needs to be emphasized here that although the study was focused on the wood industry, it aimed at testing the efficiency of the already known multi-branch prediction models (MDM) when applied to this particular industry.

It was Adamowicz and Noga (2018) who indicated the need to create a special prediction model based on homogenous (single-branch) financial information. They presented the selection process of appropriate predicators necessary to create a new model of bankruptcy prediction (FMWE). The research results showed the following financial indicators to be appropriate predicators for such a model: (i) current assets or liabilities, (ii) total income/average total assets; (iii) private capital/ total debt, (iv) profit from the operating activity - depreciation, product sales, (v) operating cost/ short-term commitments.

In this paper, research on the bankruptcy assessment of wood industry enterprises is continued. Earlier, the authors published the results regarding the applicability of multi-branch models to predict the financial situation of wood industry enterprises (Adamowicz and Noga 2014, 2017; Noga et al. 2014). This article presents an innovative bankruptcy prediction model dedicated to wood industry enterprises. A completely new proposal for forecasting bankruptcy of wood enterprises is presented. Having the previous research results in mind, as well as the fact that currently there is no branch model developed specifically for the wood industry, it was decided to conduct research, which 
would lead to constructing such a model. To corroborate the FMWE necessity for predictions it was decided to test the efficiency of the predictions provided by this model. Taking into consideration the fact that in normal business practice there are enterprises in a good financial condition as well as those, which go bankrupt, it was decided to verify the efficiency of the FMWE prediction to identify only bankruptcies and companies in a good financial condition.

\section{Methodology}

While conducting the research, econometric methods of data processing were used, which allowed to put selected bankruptcy prediction models to test by focusing on their applicability in the assessment of financial condition of wood industry enterprises. Moreover, an attempt was made to construct a prediction model dedicated to this particular branch of the economy.

The review of the literature on the subject indicated that the multiple discriminant analysis (MDA) provided a bankruptcy prediction and determined a starting point to classify healthy (healthy firms-HF) and distressed firms (failed businesses-FB). If the assumptions regarding the identical covariance matrices and multivariate normal distribution are met, MDA is likely to be more efficient than Logistics regression. Hence, the basic research method used in the process of developing the FMWE model was MDA. The predictions provided by the discriminant models use the predicting properties of financial indicators. Various studies (Altman 1968, 2002; Altman et al. 1977; Ohlson 1980; Zmijewski 1984; Shumway 2001; Duffie and Singleton 2012; Hillegeist et al. 2004; Jones and Hensher 2004, 2008; Beaver et al. 2005) focus mainly on the role of accounting-based indicators, which were used to create the FMWE model.

Enterprises, whose financial data were used, were selected on the basis of the Polish Classification of Activities (the Code List of Classification of Business Activities in Poland PKD). The analytical process used the data from enterprises where timber has been the predominant material in the production process. They came from the following PKD section symbol groups: (i) 16-sawmilling and manufacture of wood-based materials; (ii) 17-paper production and paper products; and (iii) 31-manufacture of furniture.

Prior to the empirical study, the source data were collected and cataloged in order to create a comprehensive, reliable and consistent financial database for particular wood industry enterprises. The companies were identified and divided into two groups: (i) companies that went bankrupt or initiated arrangement proceedings, and (ii) companies with a stable financial situation.

As a rule, only those enterprises, which release complete sets of financial statements, can be selected for the estimation of parametrical models. If enterprises releasing only simplified or incomplete financial statements are taken into account, it may cast doubt on the reliability of the prediction model (Hołda 2001). Hence, when compiling the financial database, all of the above aspects were considered and only full financial statements of wood industry enterprises were investigated.

The financial statements were acquired from District Courts and credit information bureaus. All the data for the enterprises in the analytical sample were collected to enable and facilitate the assessment of their financial and economic condition. The basic criterion identifying a particular company as a bankrupt/failed business (FB) was based on filing for bankruptcy - submitting a bankruptcy petition to the appropriate District Court Commercial Division. The wood sector enterprises in a stable financial and economic situation, i.e. healthy firms, (HF), were distinguished on the basis of financial information included in their balance sheets as well as profit and loss accounts, in which the indicators such as debt ratio, profitability and liquidity were of main interest.

The collected source data were comprehensive. The HF sample included only those enterprises, which did not go bankrupt during the entire research period, whereas the FB sample comprised those, which did go bankrupt in the prediction year. The enterprises, which financial data were used in the analysis were all registered and operated in Poland and they represented the following legal types of business activity: joint-stock companies, limited liability companies, general partnerships and cooperatives.

Prior to constructing the bankruptcy prediction model, a set of training data had been collected. Financial indicators were treated as independent variables in MBM. The detailed process of selecting the variables used to construct FMWE was described in a separate article by Adamowicz and Noga (2018).

To construct and test the model, financial data from 135 enterprises were used. A balanced sample $(\mathrm{N}=72=36$ $\mathrm{HF}+36 \mathrm{FB}$ ) was selected to be later used to construct the so-called raw coefficients for FMWE. To verify the obtained prediction results by means of FMWE a balanced test sample $\mathrm{T} 1(\mathrm{~N}=30=15 \mathrm{HF}+15 \mathrm{FB})$ and an unbalanced test sample $\mathrm{T} 2(\mathrm{~N}=33$ only $\mathrm{FB})$ were also used. The financial data of the enterprises in $\mathrm{T} 1$ and $\mathrm{T} 2$ were not included in the population intended for designing FMWE.

FMWE was estimated by adopting canonical analysis and. on this basis, the raw coefficients of the discriminant function were constructed. The resulting coefficients were applied to establish an empirical FMWE formula.

The discriminant power suggested by the empirical function was assessed by analyzing the ratio of intergroup variance to the intragroup variance $(\mathrm{Vi} / \mathrm{Vo})$ as well as the correlation coefficient between the discriminant results and the variable group (R). The intergroup differences 
were determined by means of square coefficient $\mathrm{R}$. The ratio of total variance in the part, which was not explained by means of intergroup variance, was provided by Wilks' lambda test.

In the later phase, numerous calculations concerning the classification function coefficients were conducted. Classification functions were used to classify the cases excluded from the study sample. It was assumed that the number of functions is equal to the number of groups. Each function was a linear combination of discriminant variables. A case was classified to this group, for which the classification function coefficient $\left(\mathrm{k}_{\mathrm{i}}\right)$ assumed the highest value.

It was also assumed that the business models for the wood industry built applying the above-mentioned research procedures classify the industries through the so-called cutoff point (threshold point), based on which the analyzed company belongs either to FB or HF. A discriminant function was created so that the mean is 0 , while the cutoff point is 0 as well.

The final stage of the study was to verify the forecast provided by the suggested FMWE. There were also predictions conducted for companies not included in the study population (T1 and T2), which financial data were not used to create FMWE. The prediction was verified based on the ex post analysis and the predictions themselves were conducted in three time variants. In the first variant, the financial data from the previous year was used to create the forecast, in the second one the data from the second year were used, while the third one comprised the data from the three years before the year of the forecast. The results of the predictions provided by FMWE were verified with the financial situation of the analyzed enterprises in the year of the forecast. Following the recommendations given by Card (1982) the accuracy rating test, i.e. the Enterprise Classification Matrix (ECM), was applied in this study. ECM is a tool, which determines the accuracy of indicators in the estimated model. The results in group $\mathrm{T} 1$ were interpreted using the following indicators: (i) the first degree error (EI); (ii) the second degree error (EII); and (iii) general efficiency (SP). In group T2, only the FB identification was analyzed, that is why the results were interpreted based on EI.

The first degree error (EI) determines what percentage of FB was erroneously classified; this was calculated by the following formula:

$\mathrm{EI}=\frac{\mathrm{NP} 1}{\mathrm{P} 1+\mathrm{NP} 1} \times 100 \%$,

$\mathrm{P} 1$ is the predicted number of FB correctly classified to the FB population, NP1 is the predicted number of HB erroneously classified to the group of FB enterprises.
The second degree error (EII) determines the percentage of erroneously classified HF; this was calculated by the following formula:

$\mathrm{EII}=\frac{\mathrm{NP} 2}{\mathrm{P} 2+\mathrm{NP} 2} \times 100 \%$,

P2 is the the predicted number of HF correctly classified to the HF population, NP2 is the the predicted number of FB erroneously classified to the HF population.

The indicators of general efficiency (SP), by which the absolute value of the correctly classified units was calculated by the formula:

$\mathrm{SP}=\frac{\mathrm{P} 1+\mathrm{P} 2}{\mathrm{P} 1+\mathrm{NP} 1+\mathrm{P} 2+\mathrm{NP} 2} \times 100 \%$.

The symbols of the previous formulas apply.

The reasoning process concerning the usefulness of the particular predictions applied to the wood industry was based on the industry classification matrix (Table 1).

\section{Results}

The previous analyses investigated five financial indicators, which constituted the independent variables; they were the most suitable for the construction of a bankruptcy prediction model for wood industry enterprises. These indicators were: (i) X1 = PRUSAK2_X3 = current assets/current liabilities, (ii) $\mathrm{X} 2=\mathrm{HOEDA} \mathrm{X} 3=$ total income $/$ mean assets, (iii) X3 = ALTMAN_X4 = equity capital/total debt, (iv) X4 =WIERZBA_ $\mathrm{X} 2$ = profit from operating activity - depreciation-to-sales ratio; (v) X5 = PRUSAK1_X2 = operating cost/short-term commitment (Adamowicz and Noga 2018). Based on the tolerance indicator it was concluded that the selected variables (indicators) are not closely correlated and can be used to create a bankruptcy prediction model of wood industry enterprises. Hence, based on the canonical analysis using the balanced sample, the wood industry discriminant function coefficients were estimated. (Table 2).

Table 1 Business classification matrix

\begin{tabular}{lll}
\hline Specification & \multicolumn{2}{l}{ Current financial situation } \\
\cline { 2 - 3 } & $\mathrm{BF}$ & $\mathrm{HF}$ \\
\hline The forecast number BF & $\mathrm{PI}$-truth & $\mathrm{NP} 2$-false \\
The forecast number $\mathrm{HB}$ & $\mathrm{NPI}-\mathrm{false}$ & $\mathrm{P} 2$-truth \\
1st degree error & $\mathrm{EI}=\mathrm{NP} 1 /(\mathrm{P} 1+\mathrm{NP} 1)^{*} 100 \%$ \\
2nd degree error & $\mathrm{EII}=\mathrm{NP} 2 /(\mathrm{P} 2+\mathrm{NP} 2) * 100 \%$ \\
General efficiency & $\mathrm{SP}=(\mathrm{P} 1+\mathrm{P} 2 /$ \\
& $(\mathrm{P} 1+\mathrm{NP} 1+\mathrm{P} 2+\mathrm{NP} 2) * 100 \%$ \\
\hline
\end{tabular}

Source: Antonowicz (2007) 
Table 2 Strict rates of the canonical discriminant function (teaching test, balanced: $\mathrm{N}=72$ )

\begin{tabular}{llllll}
\hline X1 & X2 & X3 & X4 & X5 & CMV \\
\hline 3.8767 & 0.0013 & -0.1012 & -0.0082 & 0.0003 & -0.5831 \\
\hline
\end{tabular}

$C M V$ constant model value

Source: Own research

Table 3 Summary of the canonical analysis of FMPB (teaching test, balanced: $\mathrm{N}=72$ )

\begin{tabular}{llllll}
\hline Vi/Vo & R & Lambda Wilksa & Chi-square test & df & $p$ \\
\hline 0.71 & 0.64 & 0.59 & 36.11 & 5 & 0.000 \\
\hline
\end{tabular}

Source: Own research

Table 4 Coefficients of FMPB classification functions (teaching test, balanced: $\mathrm{N}=72$ )

\begin{tabular}{lcc}
\hline Financial index & HF $p=0.50$ & BF $p=0.50$ \\
\hline X3 & -0.0704 & 0.0974 \\
X2 & 0.0032 & 0.0010 \\
X5 & 0.0008 & 0.0003 \\
X1 & 3.6984 & -2.7315 \\
X4 & -0.0172 & -0.0036 \\
Stała & -2.3680 & -1.4008 \\
\hline
\end{tabular}

Source: Own research

On the basis of the obtained results the model of bankruptcy prediction was created (FMWE).

$$
\begin{aligned}
\text { FMWE }= & -0.5831+3.8767 \times X 1+0.0013 \times X 2 \\
& -0.1012 \times X 3-0.0082 \times X 4+0.0003 \times X 5 .
\end{aligned}
$$

The next stage of the study was to assess the discriminant power of the estimated function. On this basis it was assumed that the constructed single-industry model is highly significant statistically (the $p$ value is close to zero). Thus, it is highly unlikely that the value of the discriminant function in the population of FB and HF enterprises could be identical. The conducted research indicated that the ratio of the intergroup variance to the intragroup ratio $[\mathrm{Vi} / \mathrm{Vo}]$ was 0.71 and the coefficient indicator between the discriminant results and the grouping variable $[R]$ was 0.64 . The squared coefficient presents the part of the variance, which explained the intergroup differences. In the case of this particular model, it was 0.4096 , which means that the intergroup differences explain $41 \%$ of the function variance. However, Wilks' lambda coefficient, informing on the total variance ratio, in the part not explained by the intergroup variance amounted to 0.59 (Table 3).

\begin{tabular}{|c|c|c|c|c|}
\hline \multirow{2}{*}{$\begin{array}{l}\text { The forecast is prepared on } \\
\text { the basis of data from the } \\
\text { period: }\end{array}$} & \multicolumn{3}{|c|}{$\mathrm{T} 1(15 \mathrm{HF}+15 \mathrm{FB})$} & \multirow{2}{*}{$\begin{array}{l}\mathrm{T} 2(33 \mathrm{FB}) \\
\mathrm{EI}(\%)\end{array}$} \\
\hline & $\mathrm{EI}(\%)$ & EII (\%) & $\mathrm{SP}(\%)$ & \\
\hline 1 year before verification & 0 & 27 & 89 & 18 \\
\hline 2 years before verification & 20 & 7 & 87 & 24 \\
\hline 3 years before verification & 33 & 13 & 77 & 36 \\
\hline
\end{tabular}

Table 5 Classification of enterprises using FMBP (T1 and T2)

Source: Own research

Furthermore, the classification function coefficients were calculated following the methodological assumptions. Each function is a linear combination of discriminant variables. The case was allocated to the group, for which the classifying function coefficient $\left(\mathrm{k}_{\mathrm{xi}}\right)$ assumes the highest value (Table 4):

$$
\begin{aligned}
\mathrm{k}_{1 \mathrm{i}}= & -2.3680-0.0704 \times X 3+0.0032 \times X 2 \times \\
& +0.0008 \times X 5+3.6984 \times X 1-0.0172 \times X 4, \\
\mathrm{k}_{2 \mathrm{i}}= & -1.4008+0.0974 \times X 3+0.0010 \times X 2 \\
& +0.0003 \times X 5-2.7315 \times X 1-0.0036 \times X 4 .
\end{aligned}
$$

The obtained coefficient values indicate that the discriminant power of the function is moderately high, that is why the next stage of the study focused on verifying the accuracy of FMPB predictions.

In line with the adopted methodology, the quality of the forecasts presented in the single-industry model was assessed using the ECM method (Table 1). On the basis of the FMPB predictions and using one-year financial data prior to the prediction, in group T1 all the $15 \mathrm{HF}$ were correctly identified. The forecast, however, erroneously indicated four enterprises as HF, while actually they should be FB. Among the $15 \mathrm{FB}$ only 11 were correctly classified $(\mathrm{EII}=27 \%)$. The general efficiency of FMPB predictions based on the one-year data was $89 \%$. In the group consisting solely of FB (sample T2), the prediction correctly indicated 27 out of 33 companies. Although 6 companies were incorrectly classified as HF, in reality they went bankrupt in the year of prediction (these were FB enterprises) (Table 5).

In the case of two-year predictions in group $\mathrm{T} 1$, the predictions correctly indicated 12 companies among HF. Three FB companies were erroneously classified as HF. In the FB group, 14 out of 15 companies were correctly identified. Using the data from the 2 years prior to the forecast, the general efficiency was $87 \%$. Although the data from the twoyear period prior to the forecast in the mixed $\mathrm{T} 1$ group were better at identifying FB in comparison to the predictions based on the yearly information from one year, the T2 sample does not support the correlation. While analyzing only the FB group the bankruptcy of 25 out of 33 enterprises 
was predicted accurately. Eight companies were incorrectly identified as HF, although in reality they went bankrupt in the year of the forecast (the companies were FB).

In the case of predictions created based on the three-year data interpretation, in the $\mathrm{T} 1$ group 10 out of 15 from the HF group were correctly identified. Five FB companies were incorrectly identified as HF. In the FB group, 13 out of 15 were correctly identified. Using the data from the three-year period prior to the prediction, the obtained general efficiency was $77 \%$. In the group consisting of only FB (sample T2), the prediction correctly identified 21 out of 33 companies. Twelve companies were incorrectly identified as HF, although in reality they went bankrupt in the year of the prediction (Table 5).

\section{Discussion}

The authors agree with Stiglitz (2002), who stated that in practice enterprises rely heavily on debt financing (as opposed to equity) (Mayer 1990) and go bankrupt due to insolvency. Both because of the cost of bankruptcies and the limitations in the design of managerial incentive programs, companies operate in a way that prevents risk, with risk being more than just a correlation with the business cycle (Greenwald and Stiglitz 1990; Stiglitz 1989). Considering this opinion and the opinions of other authors presented in the introduction to this paper, it needs to be recognized that bankruptcy is an important problem in the functioning of enterprises. Therefore, research looking for new models to assess the risk of enterprise bankruptcy has scientific and practical applications. The research so far clearly corroborates the validity of conducted studies aiming at the construction of a new FMWE model. According to the calculations, the accuracy of the predictions provided by the suggested FMPB has SP from 89 to $77 \%$. Significantly, in the predictions based on the data from one year prior to the forecast, the SP value was close to 90\% (89\% and 97\%).

Until now, there has been no homogenous bankruptcy prediction model specifically designed for the wood industry. Hence, any attempt at comparing the results of predictions obtained using FMWE and other homogenous models of the wood industry is futile. To interpret the effectiveness of predictions made applying FMWE, the results can and should be compared with MBM results. Adamowicz and Noga (2017) used the same methodology and the same source data as those used to assess FMWE prediction efficiency to provide forecasts and assess the efficiency of 10 most popular MBMs in Poland. The obtained results concerned the same period and the same population of companies in the T1 and T2 samples and those authors compared them with those of the presented study. Thus, the efficiency of the proposed FMWE can be postulated.
It was previously ascertained that in the assumed period, the efficiency of the FMPB predictions in group T1 was around $77-89 \%$. The average SP exceeded $84 \%$. Adamowicz and Noga (2017), on the basis of the analyses concerning the efficiency of classifying wood industry enterprises to the FB or HF group (T1), found the average SP of the MBM predictions to be $74 \%$. It seems that the average efficiency of the FMWE predictions was higher than that of the average MBM prediction. In the case of one-year predictions provided by the FMPB model, SP reached $89 \%$, while in the case of MBM, it was $77 \%$. In turn, SP of the two-year prediction based on the proposed model was $87 \%$ and in the case of MBM, it was 70\%. For FMWE SP for the three-year forecast was $77 \%$, whereas for the MBM models it amounted to $75 \%$. In all the analyzed periods, the results of the FMWE models better matched the actual situation in comparison to the results of MBM predictions.

The 1st degree error (EI), which was used to determine the percentage of incorrectly classified FBs for MBM predictions was 33\%, while for FMWE predictions it was $18 \%$. In turn, for 1-year MBM predictions it was $23 \%$, for 2-year predictions it was $42 \%$, while for 3 -year ones it was $33 \%$. In contrast, for FMWE predictions, it was $0 \%, 20 \%$ and $33 \%$, respectively. It can be concluded that as with SP, considering EI the proposed model also provided more accurate results.

The 2nd degree error (EII), used to determine the percentage of incorrectly classified HFs, was lower than for FMWE (16\%) in comparison with the average EII for MBM (19\%). In the case of MBM, the error for 1-year predictions was $22 \%$, for 2-year ones $42 \%$ and for 3-year ones $33 \%$. In turn, EII for FMWE predictions amounted to $27 \%, 7 \%$ and $87 \%$, respectively.

Adamowicz and Noga (2017), when analyzing 10 most popular bankruptcy prediction models in Poland concluded that the highest SP was recorded for predictions for the model $\mathrm{Pz}=3.562 \times$ net income/total assets $+1.588 \times$ (current assets - stocks)/current liabilities $+4.288 \times$ fixed capital/total assets $+6.7198 \times$ income from sales/sales revenue -2.368 . It should be emphasized here that the average SP in the model was $82 \%$ and was lower than SP for FMWE by $2 \%$. Furthermore, out of the 10 multi-branch models, only Pz results were characterized by SP higher than $80 \%$. Naturally, there were also models which efficiency was $54 \%$.

The analysis of efficiency for 1-, 2- and 3-year prediction models applying $\mathrm{Pz}$ and FMWE indicated that the 1- and 2-year predictions were more accurate when adopting the FMWE model. For example, for the Pz model the SP value was $86 \%$ for 1 -year predictions and $76 \%$ for 2 -year ones. Hence, the accuracy for 1-year predictions using the $\mathrm{Pz}$ model was by $3 \%$, and for 2 -year ones by $11 \%$ less accurate than that of the FMWE predictions. In the case of 3-year predictions, Pz predictions were more precise and reached $83 \%$. It was the result of better FB identification $(E I=20 \%)$. 
The prediction results based on the 3-year data prior to the verification of the prediction in terms of FB identification were slightly more accurate when the Pz model was adopted compared to the FMWE model, thus indicating that the even better adjusted bankruptcy prediction models for the wood industry still need to be searched for.

It was observed that numerous studies conducted after Altman (1968) and Ohlson (1980), similar to those presented in this paper, focused on the predictive value of financial indicators. However, a greater scope of accounting variables, including numerous non-accounting predictions such as variable market prices (Beaver et al. 2005; Hillegeist et al. 2004; Shumway 2001), corporate management proxies (Daily and Dalton, 2018) as well as recommendations and analytical predictions (Clarke et al., 2006; Jones and Johnstone, 2012) have been investigated over the years. Jones (2017) stated that the non-traditional bankruptcy variables such as concentration of the ownership/ownership structure and CEO salaries are among the strongest predicative factors. Still, the proposed FMWE model was constructed based on the traditional approach involving financial indicators, whereas possibly non-financial predicates should also have been sought. It needs to be emphasized here that no homogenous model has been developed specifically for this industry. The research results should be viewed as only a starting point for further methodological deliberations in the search of better solutions and better models. It is believed that the high SP and very low errors (EI and EII) obtained for the T1 sample imitate the real market/industry situation (i.e. the presence of FB and HB). In turn, as indicated by the great efficiency of identifying bankruptcies (sample T2), the model may be recommended for further investigations to predict the financial situation of wood sector enterprises. The authors are fully aware that FMWE, which efficiency has been confirmed in research on the Polish economy, does not necessarily have to be equally efficient in other countries. However, it does not mean that the Polish proposal cannot be applied internationally to research. Other academics may adopt/adapt and verify the efficiency of the FMWE model in the wood industry in their individual countries. The proposed prediction model may be used as a reference point for the obtained MBM results and potentially may be combined with other homogenous models to be developed, especially for this particular branch of industry. Hopefully, the FMWE model will constitute a first step in the search for future wood industry models combining multiple predictors, both financial and non-financial.

\section{Conclusion}

The article is a review paper and a summary of research to construct a bankruptcy prediction model, which will be best suited to the specific character of the wood industry. An increase may be observed in the scope of research and the number of publications concerning bankruptcy predictions for Polish wood industry enterprises. Some studies have analyzed the applicability of MBM in predicting the financial situation of wood industry enterprises (Adamowicz and Noga 2017, 2014; Noga et al. 2014). The selection process for appropriate predictors was conducted and described in detail (Adamowicz and Noga 2018). In that process, the authors followed the opinion presented by Jones (2017) indicating that an increase in the number of predictors usually leads to an excessive adjustability, which consequently reduces the general accuracy of the model. Taking into account these limitations, the financial indicators used in the most popular MBMs in Poland were applied while searching for a set of predicators suitable for FMWE. According to the recommendations given by Friedman (2000) and Hastie et al. (2005), the predictors were classified from the best to the worst based on their general prediction power. As a result, to construct FMWE five financial indicators were used and their discriminant power was determined, which was later used to construct a bankruptcy prediction model for the wood industry.

Once the FMWE model was created, the efficiency test of these predictions was conducted. In the research process, an ex post analysis was carried out to verify the predictions by comparing them with the real financial situation of these enterprises. On the basis of these results it was concluded that the FMWE model is better suited to predict the situation in the wood industry. In comparison to MBM, the predictions provided by the FMWE model were more accurate as far as bankruptcy or the financial situation are concerned. It is believed that the presented model is innovative and can be used both in research and industrial practice. The practical aspect of the results is connected with the potential applicability of the new model as a support element in the economic recovery policy in particular enterprises of the wood market chain. The scientific importance of FMWE is associated primarily with it serving as the foundation and a comparative platform for further research searching for better methodological solutions, which will contribute to even more accurate business predictions for the analyzed industry in various countries.

Acknowledgements The publication was co-financed within the framework of the Ministry of Science and Higher Education program as "Regional Initiative Excellence" in years 2019-2022, Project No. 005/ RID/2018/19. 
Author contributions Conceptualization: KA. Methodology: KA and TN. Formal analysis and investigation: TN. Writing —original draft preparation: TN. Writing—review and editing: KA. Resources: TN. Supervision: KA.

\section{Compliance with ethical standards}

Conflict of interest On behalf of all authors, the corresponding author states that there is no conflict of interest.

Open Access This article is licensed under a Creative Commons Attribution 4.0 International License, which permits use, sharing, adaptation, distribution and reproduction in any medium or format, as long as you give appropriate credit to the original author(s) and the source, provide a link to the Creative Commons licence, and indicate if changes were made. The images or other third party material in this article are included in the article's Creative Commons licence, unless indicated otherwise in a credit line to the material. If material is not included in the article's Creative Commons licence and your intended use is not permitted by statutory regulation or exceeds the permitted use, you will need to obtain permission directly from the copyright holder. To view a copy of this licence, visit http://creativecommons.org/licenses/by/4.0/.

\section{References}

Abellán J, Mantas CJ (2014) Improving experimental studies about ensembles of classifiers for bankruptcy prediction and credit scoring. Expert Syst Appl 41:3825-3830. https://doi. org/10.1016/j.eswa.2013.12.003

Adamowicz K (2010) Price elasticity of demand for timber on primary local wood market in Poland. Sylwan 154:130-138

Adamowicz K, Noga T (2014) Multivariate analysis of bankruptcy in companies in the wood sector. Sylwan 158:643-650

Adamowicz K, Noga T (2017) Assessment applicability of selected models of multiple discriminant analyses to forecast fnancial situation of Polish wood sector enterprises. Folia For Pol Ser A 59:59-67. https://doi.org/10.1515/ffp-2017-0006

Adamowicz K, Noga T (2018) Identification of financial ratios applicable in the construction of a prediction model for bankruptcy of wood industry enterprises. Folia For Pol Ser A 60:59-70. https://doi.org/10.2478/ffp-2018-0006

Afik Z, Arad O, Galil K (2016) Using Merton model for default prediction: an empirical assessment of selected alternatives. J Empir Financ 35:43-67. https://doi.org/10.1016/j.jempf in.2015.09.004

Altman EI (1968) Financial ratios, discriminant analysis and the prediction of corporate bankruptcy. J Finance 23:589-609. https ://doi.org/10.1111/j.1540-6261.1968.tb00843.x

Altman EI (2002) Bankruptcy, credit risk, and high yield junk bonds. Blackwell, Malden

Altman EI (2018) A fifty-year retrospective on credit risk models, the Altman Z-score family of models and their applications to financial markets and managerial strategies. J Credit Risk 14:1-34. https://doi.org/10.21314/jcr.2018.243

Altman EI, Haldeman RG, Narayanan P (1977) Zeta analysis: a new model to identify bankruptcy risk of corporations. J Bank Financ 7:29-54

Antonowicz P (2007) Metody oceny i prognoza kondycji ekonomiczno-finansowej przedsiębiorstw [Assessment and prediction methods for economic and financial condition of enterprises]. Ośrodek Doradztwa i Doskonalenia Kadr, Gdańsk

Beaver WH (1966) Financial ratios as predictors of failure. J Account Res 4:71-111
Beaver WH, McNichols M, Rhie JW (2005) Have financial statements become less informative? Evidence from the ability of financial ratios to predict bankruptcy. Rev Account Stud 10:93122. https://doi.org/10.1007/s11142-004-6341-9

Brezigar-Masten A, Masten I (2012) CART-based selection of bankruptcy predictors for the logit model. Expert Syst Appl 39:10153-10159. https://doi.org/10.1016/j.eswa.2012.02.125

Busu MA (2015) Financial analysis of the telecom sector. In: International Multidisciplinary Scientific Conferences on Social Sciences and Arts. Taylor \& Francis, pp 3-10

Card D (1982) Using known map category marginal frequencies to improve estimates of thematic map accuracy. Photogramm Eng Remote Sens 48:431-439

Chen N, Ribeiro B, Vieira A, Chen A (2013) Clustering and visualization of bankruptcy trajectory using self-organizing map. Expert Syst Appl 40:385-393. https://doi.org/10.1016/j. eswa.2012.07.047

Clarke J, Ferris SP, Jayaraman N, Lee J (2006) Are analyst recommendations biased? Evidence from corporate bankruptcies. J Financ Quant Anal 41:169-196. https://doi.org/10.1017/s0022 109000002465

Dąbrowska F (2008) Zarządzanie finansami przedsiębiorstwawybrane zagadnienia [Corporate financial management selected problems]. Warsaw University of Life Sciences Press, Warsaw

Daily CM, Dalton DR (2018) Bankruptcy and corporate governance: the impact of board composition and structure. Acad Manag J 37:1603-1617. https://doi.org/10.5465/256801

Delen D, Kuzey C, Uyar A (2013) Measuring firm performance using financial ratios: a decision tree approach. Expert Syst Appl 40:3970-3983. https://doi.org/10.1016/j.eswa.2013.01.012

Duffie D, Singleton KJ (2012) Credit risk: pricing, measurement, and management. Princeton University Press, Princeton

Friedman JH (2000) Greedy function approximation: a gradient boosting machine. Ann Stat 29:1189-1232

Gatti DD, Gallegati M, Greenwald BC, Russo A, Stiglitz JE (2009) Business fluctuations and bankruptcy avalanches in an evolving network economy. J Econ Interac Coord 4(2):195

Greenwald BC, Stiglitz JE (1990) Asymmetric information and the new theory of the firm: financial constraints and risk behavior (No. W 3359). National Bureau of Economic Research, Cambridge

Hastie T, Tibshirani R, Friedman J, Franklin J (2005) The elements of statistical learning: data mining, inference and prediction. Math Intell 27:83-85

Hillegeist SA, Keating EK, Cram DP, Lundstedt KG (2004) Assessing the probability of bankruptcy. Rev Account Stud 9:5-34. https:// doi.org/10.1023/B:RAST.0000013627.90884.b7

Hołda A (2001) Prognozowanie bankructwa jednostki w warunkach gospodarki polskiej z wykorzystaniem funkcji dyskryminacyjnej ZH [Forecasting bankruptcy of Polish economic entities using the $Z H$, discrimination function]. Rachunkowość 5:306-310

Jones S (2017) Corporate bankruptcy prediction: a high dimensional analysis. Rev Account Stud 22:1366-1422. https://doi. org/10.1007/s11142-017-9407-1

Jones S, Hensher DA (2004) Predicting firm financial distress: a mixed logit model. Account Rev. https://doi.org/10.2308/ accr.2004.79.4.1011

Jones S, Hensher DA (2008) Advances in credit risk modelling and corporate bankruptcy prediction. doi:10.1017/CBO9780511754197

Jones S, Johnstone D (2012) Analyst recommendations, earnings forecasts and corporate bankruptcy: recent evidence. J Behav Financ 13:281-298. https://doi.org/10.1080/15427560.2012.735299

Mayer C (1990) Financial Systems, Corporate Finance, and Economic Development. In: Hubbard RG (ed) Asymmetric information, 
corporate finance and investment. University of Chicago Press, Chicago, pp 307-332

Misankova M (2016) Credit risk and bankruptcy-critical literature review of contemporary theoretical approaches. Lecture notes in Management Science. Wiley Online Library, New York, pp 61-96

Nguyen DS, Nghiem QH, Do TPD, Nguyen LHN, Nguyen QN (2016). Building model to forecast for business bankruptcy of construction - real estate corporations in Vietnam. In: Proceedings of the 3rd International Conference on Finance and Economics 2016. Wiley Online Library, Ho Chi Minh City, pp 444-456

Noga T, Adamowicz K, Jakubowski J (2014) Metody dyskryminacyjne w ocenie sytuacji finansowej przedsiębiorstw sektora leśnodrzewnego [Discrimination methods in assessment of the financial situation of enterprises in the forestry and wood industry sector]. Acta Sci Pol Silv Colend Ratio Ind Lign 13:25-35

Ohlson JA (1980) Financial ratios and the probabilistic prediction of bankruptcy. J Account Res 18:109. https://doi.org/10.2307/24903 95

Platt HD, Platt MB (2002) Predicting corporate financial distress: reflections on choice-based sample bias. J Econ Financ 26:184199. https://doi.org/10.1007/BF02755985

Prusak B (2011) Zalety i ograniczenia modeli prognozowania zagrożenia przedsiębiorstw upadłością [Advantages and limitations of corporate bankruptcy risk prediction models]. Oficyna Wydaw SGH, Warsaw

Ribeiro B, Silva C, Chen N, Vieira A, Carvalho Das Neves J (2012) Enhanced default risk models with SVM+. Expert Syst Appl 39:10140-10152. https://doi.org/10.1016/j.eswa.2012.02.142

Shumway T (2001) Forecasting bankruptcy more accurately: a simple hazard model. J Bus 74:101-124

Singh BP, Mishra AK (2016) Re-estimation and comparisons of alternative accounting based bankruptcy prediction models for Indian companies. Financ Innov 2:1-28. https://doi.org/10.1186/s4085 4-016-0026-9

Stiglitz JE (1989) Discussion: mutual funds, capital structure, and economic efficiency. Theory Valuat Front Mod Financ Theory $1: 342-356$

Stiglitz JE (2002) Information and the change in the paradigm in economics. Am Econ Rev 92(3):460-501

Tymoszuk M (2013). Skuteczność modeli prognozowania upadłości przedsiębiorstw a upływ czasu-porównanie popularnych polskich modeli wielowymiarowej analizy dyskryminacyjnej z modelem zbudowanym przez autorkę [Effectiveness of corporate bankruptcy prediction models and the effect of time - a comparison of popular Polish multivariate discrimination analysis models with a model developed by the author], in: Adamska, E. Mączyńska (Ed.), Upadłości, Bankructwa i Naprawa Przedsiębiorstw. Wybrane Zagadnienia [Business failure, bankruptcy and restructuring of enterprises]. Warszawa

Wardzińska K (2012) Przykład zastosowania analizy dyskryminacyjnej do oceny sytuacji finansowej przedsiębiorstw [An example application for the discrimination analysis to assess the financial situation of enterprises]. Ekon i Zarządzanie 4:197-208

Wędzki D (2005) Wielowymiarowa analiza bankructwa na przykładzie budownictwa [Multivariate bankruptcy analysis based on the construction industry]. Badania Operacyjne i Decyz. 59-81

Zmijewski ME (1984) Methodological issues related to the estimation of financial distress prediction models. J Account Res. 22:59-82

Publisher's Note Springer Nature remains neutral with regard to jurisdictional claims in published maps and institutional affiliations. 